\title{
Market Response to Announcements of Mergers of Canadian Financial Institutions
}

\author{
Sebouh Aintablian \\ Lebanese American University, Lebanon \\ Gordon S. Roberts \\ York University, Canada
}

This study examines a sample of mergers of Canadian Financial Institutions during the 1990's to determine whether in-pillar, cross-pillar and foreign mergers are value-enhancing, and to determine possible sources of synergies behind those mergers. It develops testable hypotheses for Canadian FI mergers by synthesizing prior U.S. tests in the context of Canadian institutional arrangements. The overall results support the generality of findings of prior U.S. studies that the average abnormal return for both the acquiring and target firms is positive and statistically significant. This result suggests that acquisitions in the financial industry are, in Canada as elsewhere, driven by value-maximizing motivations. The study also shows that acquiring institutions' shareholders benefit more when the acquisition is of a similar type (in-pillar) and domestic (JEL: G21).

Keywords: Bank merger announcements, Canada.

\section{Introduction}

Consolidation in the financial services sector is accelerating worldwide. In the United States, the elimination of regulatory restrictions on interstate branching is resulting in the construction of a national banking system. In Europe, the introduction of the Euro is leading to increases in consolidation in order to exploit the capacity to deliver

* Financial support for obtaining the Canadian Financial Markets Research Center Database was provided by the Social Sciences and Humanities Research Council of Canada and the University Research Board, American University of Beirut. Jessie Zhang provided able research assistance. The authors benefited from comments by two referees for this journal, Lawrence Kryzanowski, Edwin Neave, Raghavendra Rau, George Tannous, Nickolaos Travlos and from participants at the Northern Finance Association 1999 Meeting , North American Finance and Economics Association 2000 Meeting, European Financial Management Association 2000 Meeting, and Multinational Finance Society 2001 Meeting

(Multinational Finance Journal, 2005, vol. 9, no. 1/2, pp. 72-98)

(C) Multinational Finance Society, a nonprofit corporation. All rights reserved.

DOI: $10.17578 / 9-1 / 2-4$ 
cross-border financial services in a single currency. In Canada, globalization, technology, deregulation and re-regulation and demographic changes are considered to be major driving forces behind consolidation in the financial services sector.

Mergers in the financial services sector can be either value maximizing or non-value-maximizing. Two further distinctions are useful in classifying mergers. First, a merger may be either in-pillar involving two financial institutions of the same type, e.g., a bank acquiring another bank or cross-pillar when acquirer and target are different types, e.g., a bank buying an insurance company. Second, mergers are either domestic if both FI's are from the home country under study or cross-border. Prior research based on U.S. data suggests value maximization as the leading motivation for mergers in the financial services sector, and in-pillar mergers as the most valueenhancing.

The goal of the present paper is to reexamine the conclusions of these U.S. studies in the Canadian context using one comprehensive data set. This is important in light of the growing literature on the significant role of institutional differences in shaping the role of financial intermediation across countries (Demiriguc-Kunt and Maksimovic, [2002]). Although Canada is next door to the U.S., its banking system is quite different. As a result, studying Canadian mergers provides a worthwhile opportunity to examine the extent to which U.S. findings on FI mergers apply internationally.

The organization of this paper is as follows: Section II reviews prior studies of mergers of financial services firms. In Section III, the article presents a brief overview of the salient features of the Canadian system. Section IV synthesizes the preceding discussions of prior research and system architecture to arrive at a series of hypotheses for empirical testing. The article presents our data and methodology in Section V. Empirical results and additional analysis of an enriched sub-sample is discussed in section VI. Section VII concludes the paper.

\section{Prior Research on Mergers in the Financial Services Sector}

\section{A. Merger motives: Value maximizing and non-value maximizing}

As stated above, the incentives for financial institutions to merge are similar to those for non-financial firms arising either from valuemaximizing or non-value-maximizing considerations. Beginning with the former, Berger, Demsetz and Strahan (1999) evaluate the causes, 
consequences, and future implications of financial services industry consolidation. An extensive literature review shows FI mergers are associated with increases in market power, improvements in profit efficiency and diversification of risks. On the other hand, there is little or no cost efficiency improvement on average. Economies of scale and scope are limited for large financial institutions with the possible exception of life insurance companies (Cummins, Tennyson and Weiss, [1999]).In an early Canadian study, Murray and White (1983) analyze the cost functions of credit unions to identify and measure the presence of economies of scale and scope in their production technology. The results show that large multi-product credit unions are more cost efficient than small, single-product ones. Nathan and Neave (1992) estimate Canadian banks' cost functions and find that Canada's concentrated banking system exploits and exhausts available sources of scale economies and cost complementarities.

FI's may merge to increase market power. Rose (1987) studies the performance of national bank mergers from 1970 to 1980 and reports that some bank mergers occur solely to increase market power. Hannan and Prager (1998) estimate a concentration-profits relationship to examine the price effects of mergers in banking. They find that, over the period 1992-1994, participants in large horizontal mergers and their competitors reduced the rates they paid on deposits to a greater extent than did banks located in markets where there were no large horizontal mergers. Akhavein, Berger and Humphrey (1997) assess the effect of "megamergers" on loan and deposit interest rates in the United States as insignificant. In contrast, Carow and Kane (2002) argue that recent large mergers harmed bank customers by increasing banks' market power. Further, the adverse publicity associated with a takeover may harm banking relationships with customers by creating uncertainties that cause some customers to switch banks. Fraser, Kolari, and Shin (2003) measure the impact of bank mergers on bank relationships in Japan documenting such an effect particularly for smaller customers.

Another group of studies contrasts two additional motives for bank mergers: diversification of earnings and assets vs. drawing on government safety nets by becoming "too big to fail". Saunders and Wilson (1999) investigate bank consolidation and safety-net provisions in Canada, the U.K. and the U.S. over a 100-year period. The study finds that consolidation reduces bank failure and that, despite increased safety-net support, bank asset-risk levels have remained flat historically. Benston, Hunter, and Wall (1995) examine the price bid to acquire 
target banks in the early to mid-1980's. Their results are consistent with the earnings diversification motive.

Prior research also focuses on non-value-maximizing motives for mergers. Managers may seek mergers in order to further their own personal interests at the expense of the shareholders. Houston and Ryngaert (1994) suggest that bank managers may be willing to undertake value reducing acquisitions if they believe that no mechanism is in place to discipline them for their actions. Benston, Hunter and Wall (1995) add that bank managers may be interested in pursuing growth to enhance their salaries, perquisites, and personal prestige. Allen and Cebenoyan (1991) find that these agency conflicts in banks are minimized through management ownership of shares and shareholder concentration.

Reinforcing evidence comes from Saunders, Strock and Travlos (1990) who compare "managerially controlled" banks, whose managers held a large portion of the bank's stock, against "stockholdercontrolled' banks. The study finds that "stockholder-controlled" banks exhibited significantly higher risk-taking behavior than "manageriallycontrolled" banks.

\section{B. Types of mergers}

The first set of studies examines in-pillar FI mergers. Houston and Ryngaert (1994) find that mergers are more profitable when the acquirer and the target operate in the same market. This type of merger allows for the closing of redundant branch and head office facilities. Cornett and De (1991) document significant positive abnormal returns for both acquirers and target banks. They suggest that there are factors unique to bank mergers that serve to increase acquirers' returns in relation to non-financial mergers. One of these factors is capital quality.

The second set of studies looks at cross-pillar mergers. These studies use the stock price response of commercial banks and securities firms to examine the risk and return effects of the announcement of bank entry into the discount brokerage industry. Saunders and Smirlock (1987) find that, while bank profitability and risk were largely unaffected by such entry, securities firms experienced a significant decline in market value. Davidson, Hatfield and Glascock (1994) examine the common stock returns of three groups of bidders purchasing brokerage houses. Only in cases in which one brokerage house purchases another are there significant abnormal returns. Neither 
of the other two groups of bidders, bank holding companies and nonfinancial firms, gain significantly when purchasing a brokerage house. Kryzanowski and Ursel (1993) examine the market reaction to announcements of legislative changes and Canadian bank takeovers of investment dealers. They find statistically significant and positive excess returns for the target investment dealers and negative excess returns for the acquiring banks. Their results suggest that any potential benefits from economies of scope in joint bank/brokerage activities were reflected in the offering prices banks paid to target investment dealers.

A third set of studies investigates cross-border mergers. Waheed and Mathur (1995) show that shareholders of U.S. banks engaged in foreign acquisitions experience significant negative abnormal returns overall but that these turn positive for the subset of acquisitions in developing countries. This suggests that, overall, the costs and risks associated with foreign acquisitions outweigh the diversification benefits expected. Peek, Rosengren and Kasirye (1999) examine foreign acquisitions of U.S. banks to determine whether the observed poor performance of foreign subsidiaries is the result of changes in business strategy attributable to the merger. The study finds that the shifts in business strategy initiated by foreign owners were generally not successful in raising the bank's performance level to that of its domestic peers. Bessler and Murtagh (2002) investigate Canadian banks' cross-border and domestic acquisitions of other financial institutions. Their findings indicate that foreign acquisitions in the wealth management and retail banking sectors created value, while foreign acquisitions in the insurance sector did not.

\section{Contribution of this study}

The purpose of this paper is to conduct tests across the entire range of merger issues using a Canadian data set. In the context of the literature reviewed above, we examine merger motivations and excess returns generated by types of mergers: in- vs. cross-pillar, domestic vs. foreign, and acquisitions in developed and developing countries. These tests add to the existing literature by testing the generality of prior findings based on U.S. data. In addition, there are a number of important differences between the financial systems and economies in Canada and the U.S. affording an opportunity to assess the impact of specific institutional arrangements on value creation in FI mergers. 


\section{Brief Overview of Financial Institutions in Canada}

A brief review of the workings of financial intermediation in Canada reveals a number of differences from the U.S. system. ${ }^{1}$ Unlike the U.S., Canada has always had a national system of coast-to-coast branching by the major banks. Traditionally, the financial sector in Canada was represented by the "four pillars": banks, insurance companies, trust companies and investment dealers. Cross-ownership between "pillars" was prohibited. The reforms of 1987-1992 introduced the possibility of mergers well before their introduction in the U.S. With these reforms came a new era of universal banking in Canada, where cross-holding of financial institutions was permitted and networking among institutions that provide different services and products was allowed. Current legislation enacted at the end of our sample period allows the formation of financial holding companies allowing banc-assurance companies on the European model although, to date, no such mergers have occurred.

During our sample period, 1990-1999, the financial services industry was dominated by the highly concentrated banking sector with the largest six banks holding $46 \%$ of the total financial services industry assets in 1997 (Task Force, 1998). Legislation in place during our sample period required banks to be widely held with ownership by one party limited to $10 \%$. As a result, all the major banks had relatively low management ownership. Further, the major banks in Canada have been widely regarded as too big to fail since the 1920's according to Kryzanowski and Roberts (1993, 1999). This suggests that, in contrast with the U.S., acquiring size in order to access implicit government guarantees is not a motive for Canadian bank mergers.

Like the banking sector, Canada's life insurance sector is also concentrated, but to a lesser degree. In 1998, over $70 \%$ of the sector's domestic assets were controlled by the top six life insurers with approximately $25 \%$ of the industry's assets in companies listed on Canadian stock exchanges. As more life insurers are demutualizing, it is expected that this sector will experience more mergers and acquisitions. Like the banks, the large life insurance companies are seen as protected by an implicit government guarantee (Roberts [1998]).

A financial services sector that has evolved significantly is the investment dealers sector. Since 1987, banks have been allowed to enter this sector. During our sample period, the bank-owned firms have about a $60 \%$ share in underwriting, about $55 \%$ of commission revenue and about $65 \%$ of fixed-income trading. ${ }^{2}$

1. Our focus here is on comparisons with the U.S. Cybo-Ottone and Murgia (2000) discuss a similar comparison of EurOpoean FI's with the U.S.

2. Investment Dealers Association of Canada, "Competition to serve Canadians - a 
Finally, the financial services sector in Canada operates in an economy that is far more closely dependent on commodity production than the U.S. As a result, the mix of foreign FI diversification between other developed and developing countries may have a different impact on value in the two countries.

\section{Testable Hypotheses}

This section develops testable hypotheses for FI mergers in the context of Canadian institutional arrangements. Table 1 summarizes our discussion with reference to the prior studies discussed above. Since target firms are given an inducement to accept an acquisition, they are expected to earn abnormal returns during the announcement, regardless of the motivation of the acquisition. Hence, the predicted impact on the target's excess return is positive for all categories of merger motivations in table 1.

If the motivation of the merger is non-value maximizing, such as growth in assets or to control a large empire, then any positive gains obtained by the target shareholders would be offset by a loss to the acquiring firm's shareholders. In this case, target firms are expected to earn positive abnormal returns, whereas acquiring firms are expected to have negative abnormal returns during the announcement period. Prior studies have noted that these conflicts may be controlled through high managerial share ownership resulting in non-negative return for the acquirer for this category in table 1 . Canada's widely-held rule results in low management ownership implying that in the presence of agency conflicts, the acquiring Canadian banks will not have positive abnormal returns.

Turning to the second category in table 1 , if the motivation for the acquisition is value-maximizing, due to diversification or synergies, there should be a positive economic gain and both the target and the acquirer should earn positive and significant abnormal returns during the announcement period. These abnormal returns are expected to be most significant if the motivation of the merger is to increase efficiency through economies of scale, economies of scope and by other revenue enhancement and cost reduction mechanisms such as closing of redundant branch and head office facilities. This is evident in Canada because of nationwide branching. In addition to banks and investment dealers, our research also studies in-pillar and cross-pillar mergers of other financial institutions: insurance, trust and finance companies. When the merger is horizontal (in-pillar) we expect to see economies

securities industry perspective" submission to the Task Force (November 1997). 


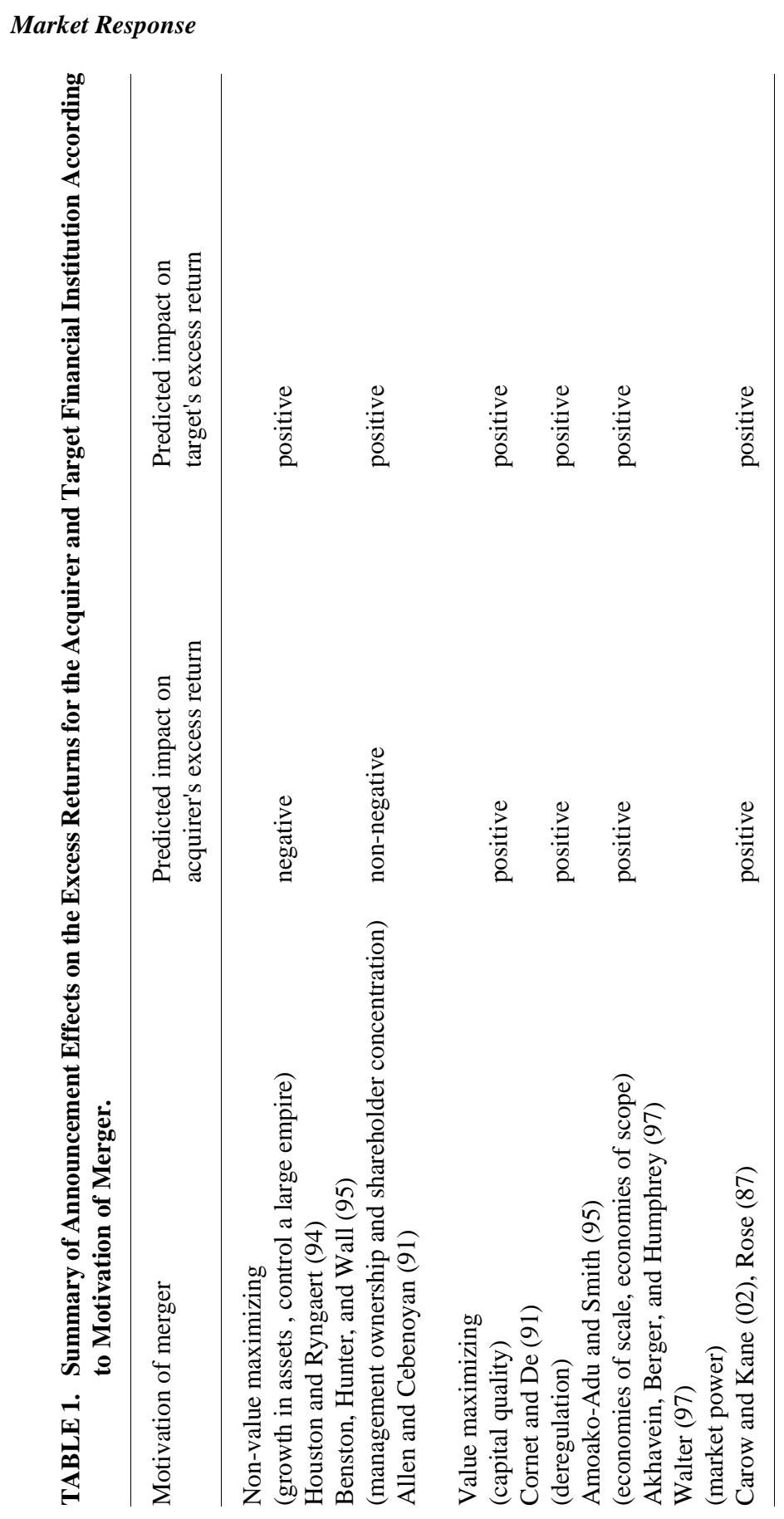


of scale, and when the merger is cross-pillar, we search for economies of scope. Beyond economies of scale, enhanced market power can result from in-pillar mergers in the same market.

Another factor unique to the financial sector is regulation. AmoakoAdu and Smith (1995) study the effects of deregulation of Canadian financial institutions. They find that only the insurance companies experienced significant shareholder gains from deregulation. ${ }^{3}$ Our study will investigate whether this is reflected in the mergers of financial institutions, giving particular focus to insurance companies.

Finally, our sample includes Canadian FI's that have acquired international financial firms. Accordingly, the research investigates whether our results support prior research conducted in U.S.

\section{Data and Methodology}

Announcements of mergers and acquisitions in the financial services sector for the period 1990-1999 are obtained from the Directory of Mergers and Acquisitions in Canada. The data provided include the type of the acquirer and the target, the announcement date, book values of equity for the acquirer and the target, and the method of acquisition. The financial institutions are classified according to Toronto Stock Exchange categories: Banks, trusts/savings and loan companies, investment companies and funds, insurance companies, and financial management companies.

In order for an FI merger to be included in our sample, at least one of the parties must be publicly traded on the Toronto Stock Exchange. As a result, our sample has more publicly traded acquirers than targets. This occurs for two reasons: first, most of the acquirers are relatively large financial institutions that are more likely to be publicly traded than the targets; second, foreign targets are excluded.

Daily stock returns are obtained from the Canadian Financial Markets Research Center (CFMRC) database. The daily returns in the CFMRC database are adjusted for dividends and stock splits. The CFMRC value-weighted index is used as the market proxy.

The market model is employed to calculate excess returns for the acquiring firm and the target around the merger event. The two-day event window $[0,1]$ is defined as the day of the announcement $(t=0)$ and the following day $(t=1)$. This procedure incorporates the possibility that some of the announcements are made after trading

3. These results are based on a sample of eight shareholder-owned insurance companies. At the time of the study, the largest insurance companies were mutuals. 
hours. ${ }^{4}$ The market model is estimated on daily returns for the period beginning 180 trading days before the event date and ending 31 trading days before the event date. The abnormal return (AR), or prediction error, for firm $j$ over day $t$ is defined as:

$$
A R_{j t}=R_{j t}-\left(\hat{\alpha}_{j}+\hat{\beta}_{j} R_{m t}\right),
$$

where $R_{j, t}$ is the rate of return of security $j$ over period $t . R_{m, t}$ is the rate of return on a value-weighted market index over period $t . \hat{\alpha}_{j}$ and $\hat{\beta}_{j}$ are the ordinary least squares estimates of firm $j$ 's market model parameters.

Announcement period excess returns are calculated by summing the abnormal returns for days 0 and 1 and then averaged over all firms within a particular group. The cumulative abnormal returns (CAR's) are calculated in a similar manner by summing the abnormal returns from day -20 to day -1 . Since this period is prior to the announcement, any positive CAR's would suggest that information leaked prior to the announcement date. Since tests of statistical significance are based on standardized prediction errors, the prediction errors are standardized by dividing by the standard error of the forecast:

$$
\begin{gathered}
S P E_{j}=\frac{\sum_{t=0}^{1} P E_{j t}}{S_{j}}, \\
S_{j}^{2}=2 v_{j}^{2}\left[1+\frac{1}{M}+\frac{\left(R_{m t}-\overline{R_{m}}\right)^{2}}{\sum_{i=1}^{M}\left(R_{m i}-\overline{R_{m}}\right)^{2}}\right] .
\end{gathered}
$$

Where $S_{J}$ is the standard error of the forecast for security $j$ in the event period, $v_{j}^{2}$ is the residual variance of the market model regression for firm $j . M$ is the number of days in the estimation period (i.e. $M=150$ ). $R_{m, t}$ is the market return in the event period. $\overline{R_{m}}$ is the mean market return over the estimation period.

The average standardized prediction error is:

4. MacKinlay (1997) states that expanding the event window in this way is a common practice unlikely introduce any significant bias. 


$$
\overline{S P E_{t}}=\frac{1}{N} \sum_{j=1}^{N} S P E_{j t} .
$$

Assuming that the individual prediction errors are cross-sectionally independent, the following $t$-statistic is calculated:

$$
t=\sqrt{N}\left(\overline{S P E_{t}}\right) .
$$

Under the null hypothesis of no announcement effect, the standardized prediction errors (SPE's) are distributed asymptotically $N(0,1)$ and the mean standardized prediction error is distributed $N(0,1 / \sqrt{N})$.

$$
H_{0}: \overline{S P E_{t}}=0
$$

For those samples that convey statistically significant results, further tests are conducted to determine whether the differences in average abnormal returns are significantly different across groups.

\section{Empirical Results}

\section{A. Full Sample Tests}

Table 2 provides full sample results for the announcements of acquisitions by Canadian financial institutions. ${ }^{5}$ The tests reported in table 2 address our value propositions. The average abnormal return (panel I) for both the acquiring and target firms is positive and statistically significant. Unlike studies for non-financial firms, and consistent with many U.S. studies, the acquiring financial firms experience a positive average abnormal return during the announcement period. This result suggests that acquisitions in the financial industry are, in general, driven by value-maximizing motivations. Acquired institutions experienced higher returns than acquiring ones for both inpillar and cross-pillar offers.

Focusing on the acquiring firms' returns in panel II, the results indicate that the AR's for acquiring FI's are less positive for foreign acquisitions $(0.68 \%)$, than for domestic ones $(1.76 \%)$. This difference

5. We focus our comments on the average residuals for the event window, $\operatorname{AR}[0,1]$. Table 2 also provides cumulative abnormal returns for the 20 days immediately preceding the event window. Note that none of the 20 day CAR's were statistically significant. 
Market Response

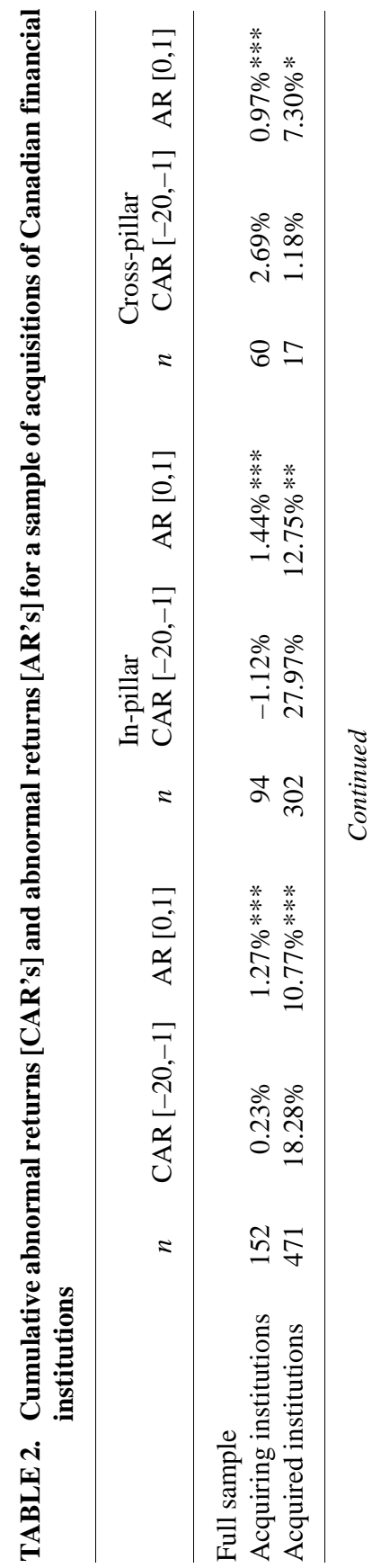




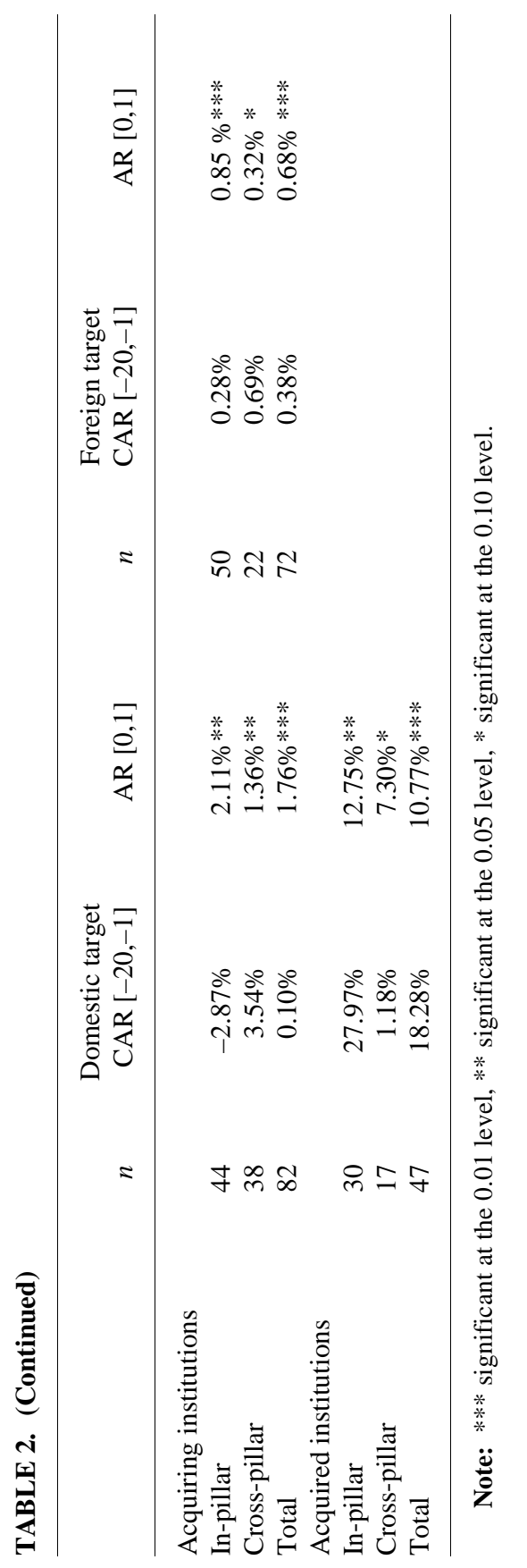




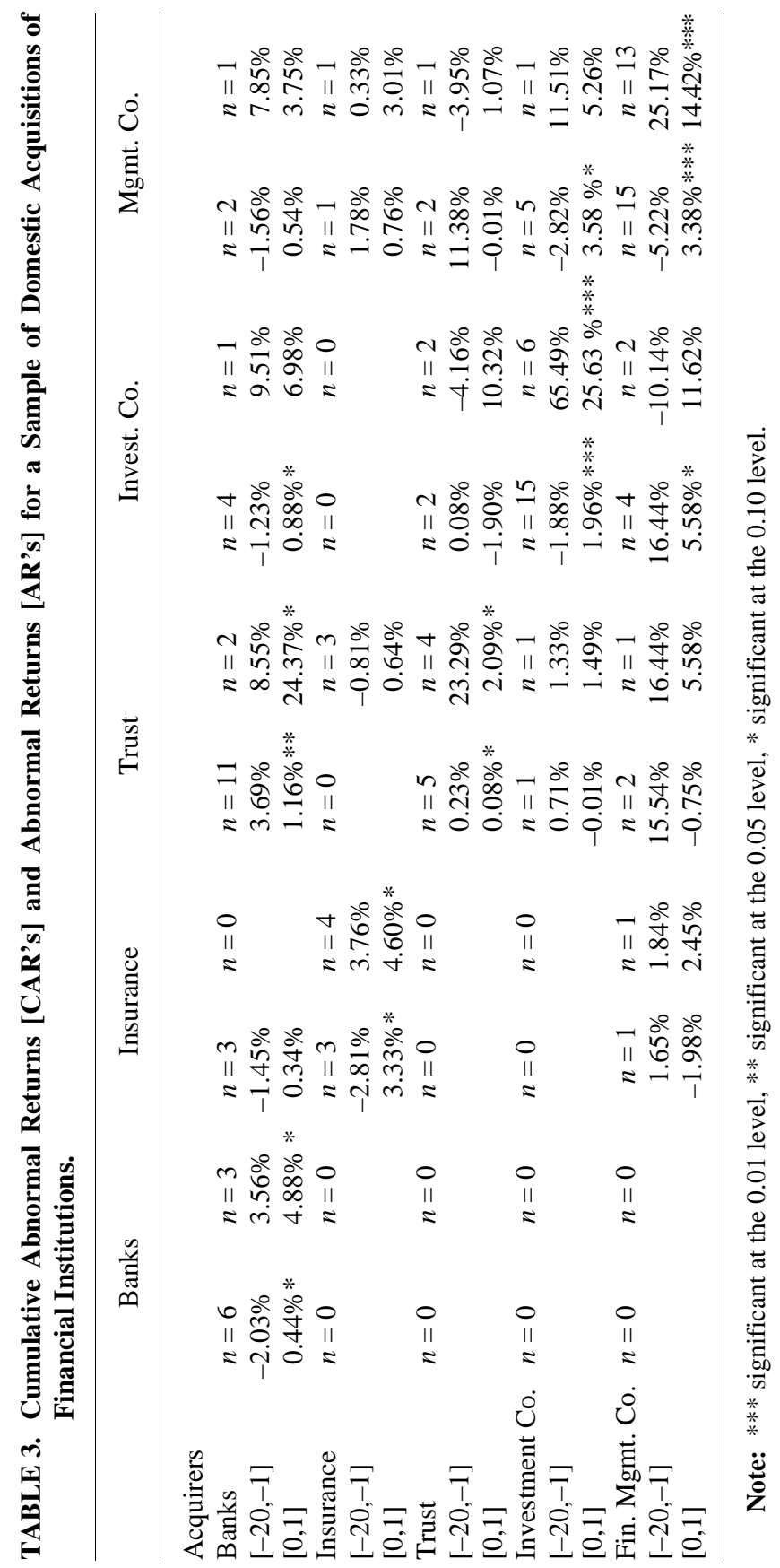


TABLE 4. Cumulative Abnormal Returns [CAR's] and Abnormals Returns [AR's] for a Sample of Foreign Acquisitions of Financial Institutions.

\begin{tabular}{lllllc}
\hline Acquirers & Banks & Insurance & Trust & Invest. Co & Fin. Mgmt. Co. \\
\hline Banks & $n=8$ & $n=0$ & $n=0$ & $n=15$ & $n=2$ \\
{$[-20,-1]$} & $1.78 \%$ & & & $1.70 \%$ & $-6.84 \%$ \\
{$[0,1]$} & $-0.47 \% * *$ & & & $0.46 \% * *$ & $-1.19 \%$ \\
Insurance & $n=0$ & $n=27$ & $n=0$ & $n=0$ & $n=0$ \\
{$[-20,-1]$} & & $-1.03 \%$ & & & \\
{$[0,1]$} & & $0.84 \% * * *$ & & & $n=0$ \\
Trust & $n=0$ & $n=0$ & $n=0$ & $n=0$ & \\
{$[-20,-1]$} & & & & & $n=0$ \\
{$[0,1]$} & & & $n=0$ & $n=11$ & \\
Invest. Co. & $n=0$ & $n=0$ & & $3.64 \%$ & \\
{$[-20,-1]$} & & & & $2.12 \% * *$ & \\
{$[0,1]$} & & & $n=1$ & $n=4$ & $n=4$ \\
Fin. Mgmt Co $n=0$ & $n=0$ & $1.33 \%$ & $2.34 \%$ & $-1.41 \%$ \\
{$[-20,-1]$} & & & $0.64 \%$ & $0.47 \%$ & $0.03 \%$ \\
{$[0,1]$} & & & &
\end{tabular}

Note: $* * *$ significant at the 0.01 level, $* *$ significant at the 0.05 level, $*$ significant at the 0.10 level.

is statistically significant and supportive of the finding of Waheed and Mathur (1995) who report that the risks and costs associated with foreign expansions out-weigh any diversification benefits from those expansions. Panel III of table 2 presents abnormal returns for acquired institutions. Because the sample studied includes data only for Canadian targets, panel III is simply a recap of the full sample (panel I). It shows that for targets, in-pillar mergers create greater value.

The next set of tests is designed to explore the sources of value. Table 3 provides the announcement effects of in-pillar and cross-pillar domestic acquisitions, classified by acquiring and acquired financial institutions. Each cell in table 3 shows returns for acquiring and target firms, respectively. For in-pillar merging institutions, significant results are observed when both firms are investment companies or financial management companies.

In table 4 the focus is on the foreign acquisitions of Canadian financial institutions classified by each type of institution. Our sample indicates that, Canadian financial institutions tend to acquire foreign targets that are of the same type. The results show that the investment companies experience the highest average abnormal return when they make foreign in-pillar acquisitions, followed by insurance firms. The difference between investment companies' average abnormal return and that of the insurance firms is significant at a $90 \%$ confidence level 
despite the small sample size. For the acquiring banks, in-pillar foreign acquisitions result in a negative average abnormal return which is significant at the $95 \%$ level. This result does not support the existence of economies of scale when domestic large banks acquire their foreign counterparts. Instead, it may indicate an increase of the overall risk level of the acquiring bank. For cross-pillar foreign acquisitions, the only notable trend is the acquisition of foreign investment companies by domestic banks. In this case, the average abnormal return for the acquiring banks is positive and significant which indicates potential existence of economies of scope in the acquisition of foreign investment companies by domestic large banks.

\section{B. How Foreign Acquisitions Differ: Sources of Synergy}

The analysis in table 4 strongly implies that foreign acquisitions differ from domestic ones. Theory suggests three main hypotheses to inform our investigation of international acquisitions:

$H_{1}$ : Management reasons such as prestige and empire building are partial determinants of foreign acquisitions (Rugman, 1980). Ceteris paribus, the expectation is for zero or insignificant abnormal returns for foreign acquisitions.

$\mathrm{H}_{2}$ : There are diversification benefits associated with acquisitions in countries whose economies are not perfectly correlated with the domestic economy (Gray and Gray, [1981]). Accordingly, the expectation is for higher and positive abnormal returns for acquisitions that occur in developing countries.

$\mathrm{H}_{3}$ : There is increased country risk associated with foreign acquisitions resulting from operational, financial, and sociopolitical factors (Haner and Ewing, 1985). As a result, lower and negative abnormal returns should be associated with acquisitions that occur in risky developing countries.

In order to investigate these hypotheses, table 5 presents new tests on international acquisitions. Panel A focuses on the returns of the Canadian acquirers classifying the foreign target FI's into two groups: U.S. targets and others. Turning to $H_{1}$, the results indicate that the AR's for acquiring banks are less positive for foreign acquisitions $(0.68 \%)$ than for domestic ones (1.76\%). This difference is statistically significant and supportive of the hypothesis. By adding a direct comparison with domestic acquisitions, this article is able to reinforce the finding of Waheed and Mathur who report negative AR's for U.S. banks making foreign acquisitions. Their paper does not make any comparison with domestic acquisitions. 
TABLE 5.

\begin{tabular}{lclclrr}
\multicolumn{2}{l}{ A. Foreign acquisitions classified by country of foreign target. } & \\
& All & Sample & U.S. & Targets & Other countries \\
& $n$ & AR [0,1] & $n$ & AR [0,1] & $n$ & AR [0,1] \\
In-pillar & 50 & $0.85 \% \%^{* *}$ & 31 & $1.04 \% * *$ & 19 & $0.54 \% *$ \\
Cross-pillar & 22 & $0.32 \% *$ & 13 & $0.55 \% *$ & 9 & $-0.44 \% *$ \\
Total & 72 & $0.68 \% * * *$ & 44 & $0.89 \% * *$ & 28 & $0.22 \% *$
\end{tabular}

B. Sale of subsidiary, division, unit, branch, and assets.

\begin{tabular}{|c|c|c|c|c|c|c|}
\hline & \multicolumn{2}{|c|}{ All } & \multicolumn{2}{|c|}{ Subsidiary } & \multicolumn{2}{|c|}{ Unit, branches, assets } \\
\hline & $n$ & $\operatorname{AR}[0,1]$ & $n$ & $\mathrm{AR}[0,1]$ & $n$ & $\operatorname{AR}[0,1]$ \\
\hline Domestic & 14 & $0.50 \%$ & 8 & $0.85 \% *$ & 6 & $0.04 \%$ \\
\hline Foreign & 23 & $0.67 \%$ & 14 & $1.09 \% *$ & 9 & $0.02 \%$ \\
\hline Total & 37 & $0.54 \%$ & 22 & $1.0027 \% *$ & 15 & $0.028 \%$ \\
\hline
\end{tabular}

Note: *** significant at the 0.01 level, $* *$ significant at the 0.05 level, * significant at the 0.10 level.

The next hypothesis $\left(\mathrm{H}_{2}\right)$ addresses possible diversification benefits from acquisitions. Waheed and Mathur report that AR's for U.S. banks making acquisitions in developed countries are negative and significant while for purchases in developing countries, the average residuals are positive and significant. In contrast, the present paper finds that U.S. acquisitions by Canadian banks result in significantly larger, positive AR's (0.89\% table 5) than do those that occurred in other countries $(0.22 \%$ table 5$)$. One possible explanation may be that, due to the important resource component, the Canadian economy is more highly correlated with those of developing countries than is the U.S. economy leading to lower diversification benefits.

Our final hypothesis $\left(\mathrm{H}_{3}\right)$ associates greater risks and costs with acquisitions in developing countries following Waheed and Mathur. The present paper confirms their result for Canadian bank acquirers by comparing domestic acquisitions (AR's 1.76\%) with foreign ones (AR's $0.68 \%$ ) and U.S. acquisitions (AR's $0.89 \%$ ) with purchases in other countries (AR's $0.22 \%$ ).

In addition to retesting the findings of Waheed and Mathur using a Canadian sample, our investigation extends their test design to examine the sale of subsidiaries, units, divisions, branches and assets of a domestic FI to domestic and foreign acquirers. As seen in panel B of table 5, the sale of foreign subsidiaries results in significantly higher AR's as compared to the sale of domestic ones. This result is consistent with $H_{1}$ and $H_{3}$ above, in the sense that, if the acquisitions of those subsidiaries show more imprudent managerial practice $\left(H_{1}\right)$ and increased risk taking $\left(\mathrm{H}_{3}\right)$, then their sale will be perceived by the 
market as enhancing efficiency and decreasing overall risk. Waheed and Mathur report that the acquisitions of foreign subsidiaries result in a $-0.47 \%$ AR for the acquirers. They interpret this as a "penalty" administered by investors to the acquiring banks. Our results suggest that it makes sense to interpret investors' reaction to the sale of foreign subsidiaries as a "reward".

Further, our tests show that the sale of subsidiaries results in strongly positive and significant AR's, whereas the sale of units, divisions, branches, or assets is associated with insignificant results. This is also consistent with the Waheed and Mathur argument that the opening of a foreign subsidiary involves greater investment and higher risks than the opening of units, divisions, or branches.

\section{Regression analysis}

A multi-variate regression is estimated for the entire sample of mergers and acquisitions with the two-day, announcement period, standardized excess return as the dependent variable. This test is performed for both the acquirers and the target financial institutions. The regression analysis has the potential to validate the other tests already discussed in several important ways. First, by employing dummy variables to classify the observations, it is possible to use the entire sample and avoid difficulties associated with small samples. Second, as a joint test on all the major variables studied, the regression allows us to measure the robustness of individual tests conducted variable by variable. In particular, robustness tests allow us to address possible overlaps between our variables.

The independent variables are: $X_{1}, X_{2}, X_{3}$ and $X_{4}$ : four dummy variables indicating the type of the financial institution as classified by the source (Mergers and Acquisitions in Canada) and according to the SIC of each FI. The four categories are: banks, insurance companies, investment companies, and financial management companies.

$X_{5}, X_{6}$, and $X_{7}$ are three dummy variables indicating: whether the acquisition is in-pillar or cross-pillar, whether the acquisition is domestic or foreign, whether the method of acquisition is cash or stock.

$X_{8}, X_{9}, X_{10}$, and $X_{11}$ are four cross-dummy variables indicating: whether the acquisition is in-pillar and the FI is an insurance company, whether the acquisition is in-pillar and the FI is an investment company, whether the acquisition is in-pillar and the FI is a financial management company, whether the acquisition is in-pillar and domestic.

The regression equation is: 
TABLE 6. Results of Regression of Standardized Excess Returns on Various Standardized Dummy Variables for a Sample of FI Mergers from 1990-1999.

\begin{tabular}{lcccc}
\hline & \multicolumn{2}{c}{ Aquirers } & \multicolumn{2}{c}{ Targets } \\
Variable & coefficient & $t$-stat & coefficient & $t$-stat \\
\hline X1 (1 if bank) & -0.03 & 0.63 & 0.04 & 0.23 \\
X2 (1 if Insurance co) & 0.023 & 1.46 & 0.07 & 0.05 \\
X3 (1 if Investment co) & 0.008 & 0.87 & 0.04 & 0.74 \\
X4 (1 if Fin .Mngt Co) & 0.019 & 1.52 & 0.27 & 1.32 \\
X5 (1 if in-pillar) & 0.43 & $2.11^{* *}$ & 0.34 & $1.98^{* *}$ \\
X6 (1 if domestic) & 0.52 & $2.21^{* *}$ & 0.28 & $1.82^{*}$ \\
X7 (1 if "cash" acquisition) & 0.51 & $1.79^{*}$ & 0.36 & 1.16 \\
X8 (1 if Insurance co and in-pillar) & 0.32 & $1.71^{*}$ & 0.36 & 0.45 \\
X9 (1 if Investment co and in-pillar) & 0.38 & $2.27^{* *}$ & 0.13 & $1.68^{*}$ \\
X10 (1 if Fin. Mngt Co and in-pillar) & 0.59 & $2.01^{* *}$ & 0.37 & $2.05^{* *}$ \\
X11 (1 if in-pillar and domestic) & 0.61 & $3.85^{* * *}$ & 0.49 & $3.06^{* * * *}$ \\
Intercept & 0.02 & & & \\
$R$-square & 0.29 & & & \\
\hline
\end{tabular}

Note: *** significant at the 0.01 level, ** significant at the 0.05 level, * significant at the 0.10 level. Note that $\mathrm{X} 8=\mathrm{X} 2 \times \mathrm{X} 5, \mathrm{X} 9=\mathrm{X} 3 \times \mathrm{X} 5, \mathrm{X} 10=\mathrm{X} 4 \times \mathrm{X} 5, \mathrm{X} 11=\mathrm{X} 5 \times \mathrm{X} 6$. All dummy variables are assigned the value of zero otherwise.

$$
S E R_{i}=\frac{D_{0}}{\sigma_{i}}+\sum_{i=1}^{i=11} \frac{D_{i} X_{i}}{\sigma_{i}}+\frac{\varepsilon_{i}}{\sigma_{i}}
$$

$S E R_{i}$ is the two day standardized excess return for stock $i, D_{0}$ is the intercept, $D_{1}, \ldots, D_{11}$ are the coefficients of the dummy variables, $X_{1}, \ldots$, $X_{11}$ are the independent variables, and $\sigma_{i}$ is the standard error of the excess returns for stock $i$.

Table 6 presents the regression results. The coefficients for all the variables describing the type of FI $\left(X_{1}, \ldots, X_{4}\right)$ are not significant suggesting that the abnormal returns cannot be explained by the type of FI. The coefficient for in-pillar acquisitions $\left(X_{5}\right)$ is positive and significant for both the acquirers and targets, which supports the earlier results of table 2. This indicates that the market perceives in-pillar acquisitions as value-maximizing, and that, there are potential economies of scale as a result of those acquisitions. To examine inpillar acquisitions further, cross-dummies $\left(X_{8}, X_{9}\right.$, and $\left.X_{10}\right)$ are employed. The coefficients for the three cross-dummies are all positive and in the case of acquirers more significant, thus confirming the earlier results in table 3 and 4 that the most significant abnormal returns are realized when acquisitions are in-pillar for insurance companies, 
investment companies, and financial management companies. These findings are supportive of prior results obtained by Amoako-Adu and Smith (1995) for insurance companies and by Davidson, Hatfield and Glascock (1994) for brokerage houses.

The coefficient for domestic acquisitions $\left(X_{6}\right)$ is also positive and significant consistent with Houston and Ryngaert (1994) who find that mergers are more profitable when the acquirer and the target operate in the same market. They conclude that mergers with a higher degree of market overlap are viewed positively by the market. This is particularly evident in Canada because of nationwide branching.

The coefficient for the last cross-dummy $\left(X_{11}\right)$ is positive and significant confirming that the acquisitions are perceived to be valueenhancing when they are jointly in-pillar $\left(X_{5}\right)$ and domestic $\left(X_{6}\right)$. Kane (2000) finds that banking organizations gain additional value when they absorb an in-state competitor. Our results for the cross-dummy $\left(X_{11}\right)$ support Kane's finding, as, in our Canadian context, "domestic and inpillar" is analogous to "in-state competitor" in his U.S. sample.

The coefficient for "cash" acquisitions $\left(X_{7}\right)$ is positive and significant, for the acquirers which confirms the results of prior studies for corporate mergers. Travlos (1987) and Brown and Ryngaert (1991) find that the bidding firms perform worse when they offer stock rather than cash. For financial firms, Cornett and De (1991) find no significant relationship between acquirer abnormal return and the mode of acquisition. However, Hawawini and Swary (1990) report that acquirers receive higher abnormal returns when the acquisition is paid for in cash. Houston and Ryngaert (1994) find that the increased use of stock results in more negative returns. Our results confirm that the abnormal return of the acquirer is related to the mode of acquisition.

\section{Robustness Testing}

Our market model tests could be subject to error if the merger events under study introduce changes in total, systematic, or unsystematic risks. Such risk shifts could result if mergers have a risk-reducing diversification effect, for example. To determine if the tests discussed above suffer from such error, it is appropriate to conduct a regression following Waheed and Mathur (1995), testing whether the changes in total risk, systematic risk, and unsystematic risk explain variations in wealth effects associated with merger announcements. In this regression, the dependent variable is the standardized announcement period excess return, and the independent variables are three proxies for changes in total risk, systematic risk, and unsystematic risk.

$$
S P E_{i}=b_{1} \Delta T V A R+b_{2} \Delta S Y S+b_{3} \Delta U N S Y S+\varepsilon_{i}
$$


Where

$$
\begin{gathered}
\Delta T V A R=\frac{V A R R_{i} \text { post }- \text { VARR } R_{1} r e}{V A R R_{i} p r e}, \\
\Delta S Y S=\frac{\left(\beta_{i} \text { post }-\beta_{i} p r e\right)}{\beta_{i} p r e}, \\
\Delta U N S Y S=\frac{\left(V A R \varepsilon_{i} p o s t-V A R \varepsilon_{i} p r e\right)}{V A R \varepsilon_{i} p r e} .
\end{gathered}
$$

The regression results are:

$$
\begin{gathered}
S P E_{i}=-0.089 \Delta T V A R+-0.057 \Delta S Y S+-0.0230 U N S Y S+\varepsilon_{i} \\
(t=-1.02) \quad(t=-0.82) \quad(t=-0.47)
\end{gathered}
$$

The results reveal that there is no statistically significant relationship between measures of risk shifts and announcement period excess return. This suggests that our model is robust.

\section{E. Additional Analysis}

This section considers the impact of some further relevant factors by examining sub-samples for which a richer set of information is available. ${ }^{6}$ Table 7 creates a sub-sample of twelve domestic mergers for which market capitalizations are available for both acquirer and target. This sub-sample allows us to investigate the wealth creation effects of FI mergers as distinct from the percentage excess returns. These may differ because, in many cases, the acquirer is far larger than the target. Beginning with the mean excess returns at the bottom of the table, it is clear that the sub-sample conforms to the population with mean target excess return of 15.78 percent, an order of magnitude larger than the corresponding mean excess return for the acquirer of 0.14 percent. Examining the twelve cases individually shows that the target excess return is higher in every case.

To move from percentage excess returns to wealth creation requires multiplying each excess return by the firm's market capitalization to obtain excess returns in dollars. Comparing the mean dollar excess returns for acquirers and targets reinforces our earlier conclusion: on average, excess returns are higher for targets than for acquirers. Turning to individual mergers reveals that this conclusion is reversed in four

6. We are grateful to a referee for suggesting these added lines of analysis. 


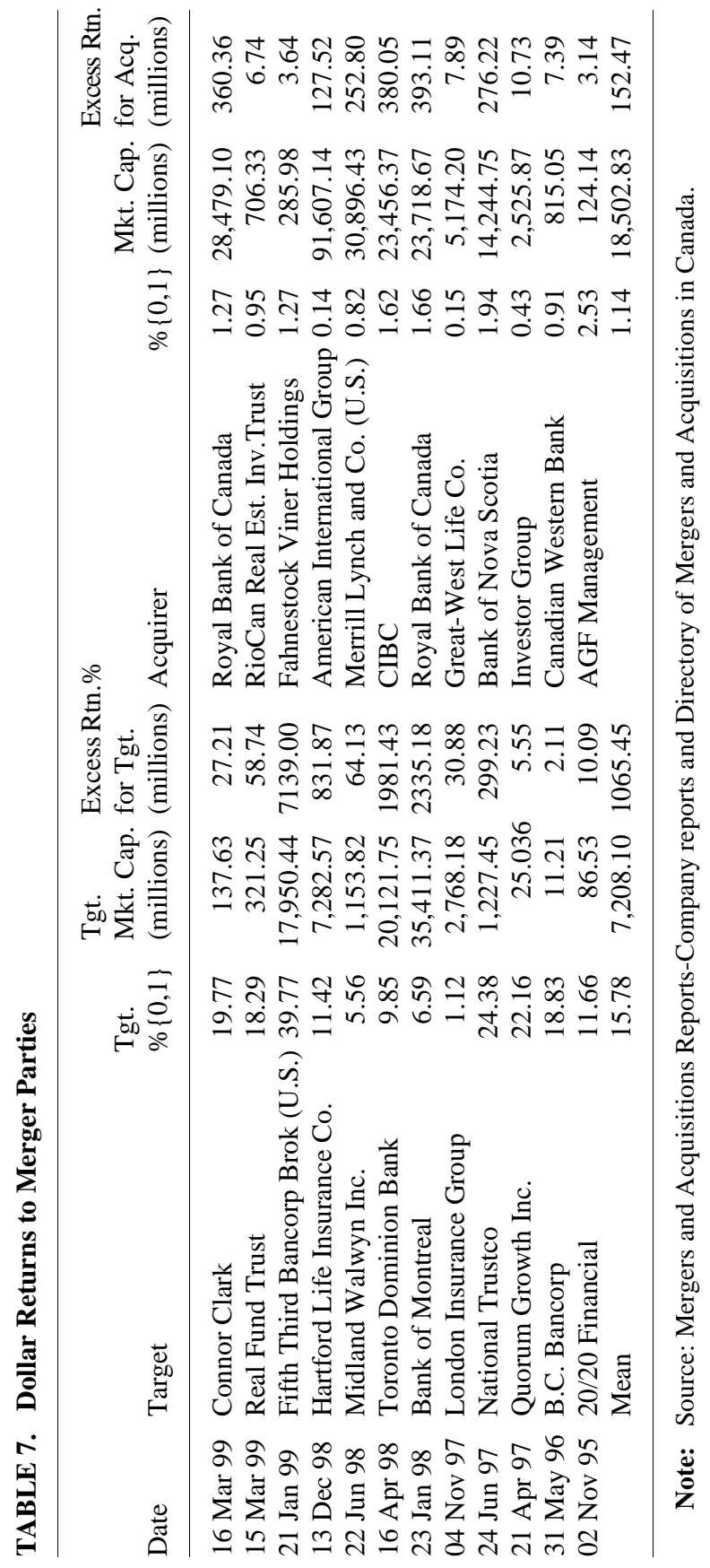


cases in which gigantic acquirers merged with far smaller entities. For example, on 16 March 1999, Royal Bank of Canada (market capitalization of $\$ 28,479.10$ million) acquired Connor Clark (market capitalization of $\$ 137.63$ million). The target shares had a higher percentage excess return (19.77) compared to $1.27 \%$ for Royal Bank. Due to the large disparity in market capitalization the dollar return to Royal Bank was \$360.36 million vs. only \$27.21 million for Connor Clark.

Two further cases of particular interest involve announcements of mergers of equals: Royal Bank of Canada -Bank of Montreal and CIBC -Toronto Dominion Bank. In both cases the announcement period excess percentage and dollar returns were far higher for the target. Both

these proposed mergers of equals were disallowed by the Minister of Finance and never occurred.

Continuing with our theme in this section of enriching information for a sub-sample of mergers, table 8 provides information regarding the method (cash vs. stock) and the nature (hostile/friendly) of a sample of acquisitions along with the associated average market premiums. Due to data limitations, relevant information is available for only a small fraction of the total merger announcements. In panel A of table 8, for all categories (Canadian, U.S. and international targets), more than half of the mergers were financed by cash, and the rest either by stock or a combination of cash and stock. Panel B of table 8 shows that, in general, friendly mergers dominated hostile ones. Finally, in panel $\mathrm{C}$ of table 8 , there are no significant differences in market premiums comparing hostile against friendly mergers and comparing Canadian mergers with the total sample.

\section{Conclusions}

This paper examines market reaction to the announcement of mergers of Canadian financial institutions during the period 1990-99. The overall results support the generality of findings of prior U.S. studies. In particular, the average abnormal return for both the acquiring and target firms is positive and statistically significant. In contrast with nonfinancial acquiring firms, and consistent with findings of U.S. researchers, acquiring financial firms experience a positive average abnormal return during the announcement period. This suggests that acquisitions in the financial industry are, in Canada as elsewhere, driven by value-maximizing motivations. Our study also shows that acquiring institutions' shareholders benefit more when the acquisition is of a similar type (in-pillar) and when it is domestic. The most significant abnormal returns are realized when acquisitions are in-pillar 
TABLE 8.

\begin{tabular}{|c|c|c|c|c|}
\hline \multicolumn{5}{|c|}{ A. 88 Acquisitions classified by method of payment. } \\
\hline Cash & 50 & 23 & 19 & 8 \\
\hline Stock & 19 & 17 & 2 & 0 \\
\hline Cash/stock & 19 & 13 & 4 & 2 \\
\hline Total & 88 & 53 & 25 & 10 \\
\hline \multicolumn{5}{|c|}{ B. 55 acquisitions classified as hostile, friendly, and unknown. } \\
\hline & Sample & nadian Target & U.S. Target & Int. Target \\
\hline Hostile & 17 & 14 & 0 & 3 \\
\hline Friendly & 38 & 20 & 15 & 3 \\
\hline Total & 55 & 34 & 15 & 6 \\
\hline \multicolumn{5}{|c|}{ C. Average market premium for a sub-sample of 13 acquisitions. } \\
\hline & Total & Sample & Canadian & Sample \\
\hline & Avg...Mkt. prem. & $n$ & Avg...Mkt. prem. & $n$ \\
\hline Hostile & $28.93 \%$ & 10 & $28.25 \%$ & 9 \\
\hline Friendly & $32.25 \%$ & 3 & $39.19 \%$ & 2 \\
\hline Total & $29.70 \%$ & 13 & $30.24 \%$ & 11 \\
\hline
\end{tabular}

Note: Source: Mergers and Acquisitions Reports-Company reports and Directory of Mergers and Acquisitions in Canada.

for insurance companies, investment companies, and financial management companies. Our results show that the degree of market overlap and the mode of acquisition are associated positively with the abnormal returns. This supports the argument of Kane (2000) and Carow and Kane (2002) identifying increased market power as an important motivation for FI mergers. Further, in contrast to the U.S. banks they studied, the Canadian acquirers in our sample are primarily large banks already too big to fail. As a result, our findings can be interpreted as a clear test of market power without the confounding effect of enhanced access to implicit guarantees.

Our findings diverge from those of prior studies for the subset of foreign acquisitions. Waheed and Mathur (1995) report that U.S. shareholders are losers when their financial institutions make foreign acquisitions. The article also finds for Canadian institutions that foreign acquisitions are associated with less positive abnormal returns. Within foreign acquisitions, relative value can be explained by their distribution between developed and emerging markets. The relationship, however, is exactly the opposite what Waheed and Mathur report. While their study finds that U.S. banks create value when they acquire financial institutions in developing countries, our tests uncover the greatest value for Canadian acquirers in the U.S. market. While empire building, diversification benefits and country risk explain value creation in foreign acquisitions for both Canadian and U.S. banks, their 
impact is different across borders as a result of differences between the U.S. and Canadian economies.

\section{References}

Akhavein, J. D., A. N. Berger, and D.B. Humphrey, 1997. The effects of megamergers on efficiency and prices: Evidence from a bank profit function. Review of Industrial Organization 12: 95-139.

Allen, L., and A. S. Cebenoyan, 1991. Bank acquisitions and ownership structure: Theory and evidence. Journal of Banking and Finance 15: 425448.

Amoako-Adu B., and B. F. Smith, 1995. The wealth effects of deregulation of Canadian financial institutions. Journal of Banking and Finance 19: 12111236.

Benston, G. J., W. C. Hunter, and L. D. Wall, 1995. Motivations for bank mergers and acquisitions: Enhancing the deposit insurance put option versus earnings diversification. Journal of Money Credit, and Banking 27: 777-788.

Berger, A. N., R. S. Demsetz, and P. Strahan, 1999. The consolidation of the financial services industry: Causes, consequences, and implications for the future. Journal of Banking and Finance 23, issue 2-4 : 135-194.

Bessler, W., and J. P. Murtagh, 2002. The stock market reaction to cross-border acquisitions of financial services firms: An analysis of Canadian banks. Journal of International Financial Markets, Institutions and Money 12: 419-440.

Carow, K. A and E. J. Kane, 2000. Event-study evidence of the value of relaxing longstanding regulatory restraints on banks, 1970-2000. Quarterly Journal of Economics and Finance 42 (Summer): 439-463.

Cornett, M. M., and S. De, 1991. Common stock returns in corporate takeover bids: Evidence from interstate bank mergers. Journal of Banking and Finance 15: 273-295.

Cummins, J. D., S. Tennyson, and M.A. Weiss, 1999. Consolidation and efficiency in the U.S. life insurance industry. Journal of Banking and Finance 23, issue 2-4 : 325-357.

Cybo-Ottone, A. and M. Murgia, 2000. Mergers and shareholder wealth in European banking. Journal of Banking and Finance 24 (June): 831-859.

Davidson, W. N., G. Hatfield, and J. L. Glascock, 1994. Common stock returns in corporate takeover bids: The case of brokerage house acquisitions. Financial Review 29 (February): 77-96.

Demiriguc-Kunt, A. and V. Maksimovic, 2002. Funding growth in bank-based and market-based financial systems: Evidence from firm-level data. Journal of Financial Economics 65 (September): 337-364.

Fraser, D. R., J. W. Kolari, and G. Hwan Shin, 2003. How does banking industry consolidation affect bank-firm relationships? Evidence from a large Japanese bank merger. Pacific-Basin Finance Journal.

Gray, M. and P. Gray, 1981. The multinational bank: A financial MNC? Journal of Banking and Finance 5, 33-63. 
Haner, F. T. and J.Ewing, 1985. Country risk assessment: theory and worldwide practice. New York, N.Y.: Praeger Publishers.

Hannan, T. H. and R. A. Prager, 1998. Do substantial horizontal mergers generate significant price effects? Evidence from the banking industry. Journal of Industrial Economics 46 (December): 433-52.

Hawawini, G. and I. Swary, 1990. Mergers and acquisitions in the U.S. banking industry. New York, N.Y.: Elsevier Science Publishers.

Houston, J. F., and M. D. Ryngaert, 1994. The overall gains from large bank mergers. Journal of Banking and Finance 18: 1155-1176.

Kane, E. J., 2000. Incentives for banking mega-mergers: What motives might regulators infer from event-study evidence? Journal of Money, Credit, and Banking 32: 671-701.

Kryzanowski L., and G. S. Roberts, 1993. Canadian bank solvency,1922-1940. Journal of Money, Credit and Banking 25:361-376.

Kryzanowski L., and G. S. Roberts 1999. Perspectives on Canadian bank insolvency during the 1930s. Journal of Money, Credit and Banking.31:130-136.

Kryzanowski, L., and N. Ursel, 1993. Market reaction to announcements of legislative changes and Canadian bank takeovers of Canadian investment dealers. Journal of Financial Services Research 171-185.

MacKinlay, A. C. 1997. Event studies in economics and finance. Journal of Economic Literature 35: 13-39.

Murray, J. D., and R. W. White, 1983. Economies of scale and economies of scope in multi-product financial institutions: A study of British Columbia credit unions. Journal of Finance 38: 887-902.

Nathan, A., and E. H. Neave, 1992. Operating efficiency of Canadian banks. Journal of Financial Services Research 6: 265-276.

Peek, J., E. S. Rosengren, and F. Kasirye, 1999. The poor performance of foreign bank subsidiaries: Were the problems acquired or created? Journal of Banking and Finance 23: 579-604.

Rose, P. S., 1987. The impact of mergers in banking: Evidence from a nationwide sample of federally chartered banks. Journal of Economics and Business 39: 289-312.

Rugman, A. M., 1980. Multinationals in Canada: Theory, performance and economic impact. Boston, Mass.: Martinus Nyhoff.

Ryngaert, M. D. and D. Brown, 1991. The mode of acquisitions in takeovers: Taxes and asymmetric information. Journal of Finance 46: 653-669.

Saunders, A., and M. Smirlock, 1987. Intra- and inter-industry effects of bank securities market activities: The case of discount brokerage. Journal of Financial and Quantitative Analysis 22: 467-482.

Saunders, A. E. Strock, and N. G.Travlos, 1990. Ownership structure, deregulation, and bank risk taking. Journal of Finance 45: 643-654.

Saunders, A., and B. Wilson, 1999. The impact of consolidation and safety-net support on Canadian, U.S. and U.K. banks: 1893-1992. Journal of Banking and Finance 23: 537-571.

Task Force on the Future of the Canadian Financial Services Sector", 1998. Chapters 1-3, www.finservtaskforce.fin.gc.ca.

Travlos, N., 1987. Corporate takeover bids, the method of payment and bidding firms' stock returns. Journal of Finance 42: 943-963. 
Waheed, A. and I. Mathur, 1995. Wealth effects of expansion by U.S. banks. Journal of Banking and Finance 19: 823-42. 